Dominika Kossowska-Janik

Uniwersytet Warszawski, Warszawa

\title{
Gdy cesarzowa piła herbatę... Historia chińskiego jedwabiu od neolitu do czasów panowania dynastii Tang
}

Cywilizacja chińska, choć zrodziła wiele wynalazków, kojarzona jest przede wszystkim z jedwabiem ${ }^{1}$, który do dziś jest towarem luksusowym i prestiżowym. Hodowla jedwabnika na ziemiach chińskich rozpoczęła się już w neolicie. O jej początkach opowiadają dworskie legendy i ludowe podania. Jedwab stał się symbolem chińskiej kultury. Jak pisze Luce Boulnois (1968: 22): „Jedwab zaczął służyć jako środek płatniczy, którym regulowano pobory urzędnikom i wynagradzano wszelkie usługi; magazynowano zasoby jedwabiu i przechowywano je, tak jak przechowywano zapasy złota; liczyło się w sztukach jedwabiu, tak jak liczono w funtach złoto". Wraz z rozwojem kultury następował postęp w technologii tkackiej. Tkaniny jedwabne w języku chińskim były nazywane od rodzaju splotu bądź zdobienia. Tak więc powstał szereg terminów, które nieraz budzą kontrowersje wśród językoznawców i archeologów.

W literaturze zagranicznej powstało wiele opracowań na temat chińskich jedwabi. Dotyczą one zarówno historii serikultury (jedwabnictwa), znaczenia jedwabiu w kulturze chińskiej, jego wartości

${ }^{1} \mathrm{~W}$ niniejszym artykule terminy włókiennicze są podawane według Leksykonu włókiennictwa Marty Michałowskiej (2006). 
„rynkowej”, roli w rozwoju handlu dalekosiężnego, a także technicznego opisu typów tkanin, ich nazewnictwa, splotów, technik barwienia i zdobienia (np. Becker 1987; Wang 2013: 165-174; Zhao 2002; Kuhn 1988). W 2012 r. wydano pozycję pod redakcją Dietera Kuhna i Zhao Fenga (Chinese Silks), która jest doskonałym podsumowaniem dotychczasowej wiedzy na temat tkanin jedwabnych. Z kolei w literaturze polskiej brakuje publikacji traktujących o historii rozwoju chińskich technik tkackich. Znacznie większy nacisk kładzie się na znaczenie jedwabiu $\mathrm{w}$ handlu dalekosiężnym oraz rozwój produkcji jedwabniczej na terenie Bliskiego Wschodu i Europy (np. Żarnowiecki 1915; Nahlik 1971). Wyjątkiem jest książka Aleksandry i Edwarda Kajdańskich (2007), Jedwab. Szlakami dżonek i karawan, gdzie znajduje się rozdział poświęcony poszczególnym typom tkanin chińskich.

Włókno jedwabiu to oprzęd udomowionej gąsienicy gatunku Bombyx Mori. Jest ono zbudowane z dwóch typów białek. Rdzeń włókna stanową dwie wiązki fibroiny, które otoczone są serycyną. Tajemnica jakości chińskiego surowca kryła się w umiejętności oczyszczenia go z serycyny (tzw. klej jedwabny). Można ją usunąć poprzez gotowanie kokonu w lekko zasadowym roztworze. Jeśli proces ten nastąpił przed wyjściem gąsienicy, po ugotowaniu dało się rozwinąć jedwabną nić bez potrzeby dodatkowego przędzenia. W momencie opuszczania kokonu przez jedwabnika włókna zostają nadgryzione, dlatego też surowiec otrzymany z pustych kokonów wymagał dodatkowej obróbki. W wyniku oczyszczenia jedwabiu otrzymywano niezwykle cienką i błyszczącą nić, z której tkano wyrafinowane i pożądane w antycznym świecie wyroby włókiennicze. W tkactwie wykorzystywano także włókna produkowane przez inne gatunki jedwabnika, które nigdy nie zostały udomowione. Najstarsze znaleziska tkanin wykonane $\mathrm{z}$ tego surowca pochodzą z Cywilizacji Doliny Indusu (2800-1500 p.n.e.) (Good 2009: 457-466). Dziki jedwab prawdopodobnie był także znany w kulturze egejskiej (Ulanowska 2013: 47-48). Nie dość, że włókna pozyskiwane z kokonów dzikich jedwabników wymagają przędzenia, więc nigdy nie będą tak cienkie i trwałe jak greża ${ }^{2} \mathrm{z}$ kokonów jedwabnika morwowego (Bombyx Mori), to $\mathrm{w}$ dodatku $\mathrm{z}$ dzikiego jedwabiu nie łatwo usunąć serycynę, przez co większość materiałów wykonanych z tego surowca nie jest pozbawiona „kleju jedwabnego” (Good 1995: 961).

Jedwabnik był hodowany w większości chińskich gospodarstw. Proces ten jest niezwykle żmudny i długotrwały. Początkowo należy

\footnotetext{
${ }^{2}$ Greża to nieskręcona nić surowego jedwabiu, otrzymana dzięki łączeniu włókien z kilku kokonów.
} 
utrzymać jajeczka jedwabnika w stałej temperaturze. Kiedy wylęgną się gąsienice, należy je karmić drobno posiekanymi liśćmi morwy co pół godziny. Gdy jedwabniki dorastają, należy je chronić przed hałasem, przeciągami i ostrymi zapachami. Po mniej więcej czterech tygodniach gąsienice zaczynają produkować oprzęd, wtedy umieszcza się je na ryżowych matach trzymanych w cieple. Owijanie trwa około 3 dni. We właściwym momencie (nim gąsienica przegryzie kokon) kokony należy wrzucić do gorącej wody w celu usunięcia serycyny. Tradycyjne jedwabnictwo we współczesnych Chinach i Azji Południowo-Wschodniej nie różni się od starożytnej hodowli, o czym świadczą teksty historyczne i przedstawienia ikonograficzne (Kuhn 1988: 285-344).

Z początkiem serikultury wiąże się wiele chińskich legend. Według jednej z nich, spisanej w Księdze Dokumentów (Shujing), tradycję jedwabniczą miała zapoczątkować żona Żółtego Cesarza, która spacerując po ogrodzie, dostrzegła na morwie jedwabnika owijającego się w kokon. Cesarzowa rozwinęła nitkę i utkała pierwszy jedwabny materiał (Uhlig 2007: 14-15). Według innego przekazu, gdy cesarzowa pod morwą piła herbatę, do jej filiżanki z drzewa spadł kokon jedwabnika. Cesarzowa wyjmując go, rozwinęła pierwszą nitkę jedwabiu. Pewna bajka ludowa opowiada natomiast o mężczyźnie, który wyruszył w świat, zostawiwszy w domu żonę z dzieckiem. Kobieta przyrzekła, że wyda córkę za tego, kto sprowadzi jej męża do domu. Okazało się, że uczynił to ich koń, który zamiast otrzymać nagrodę, został zabity. Gdy dziewczynka skakała przez rozwieszoną skórę konia, ta owinęła się wokół niej, tworząc pierwszy kokon jedwabnika (Uhlig 2007: 16). Z kolei w Syczuanie lud Bo wierzy, że to król Zanzong z państwa Shu wyszedł z gąsienicy jedwabnika, dając początek tradycji tkania z jedwabiu (Uhlig 2007: 15). Warto zaznaczyć, że serikultura odcisnęła silne piętno na chińskiej mitologii i religijności. Czczono nie tylko legendarnego pierwszego hodowcę, boginie poświęcone jedwabnikom, ale także i samego jedwabnika, któremu składano ofiary i budowano świątynie (Kuhn 1988: 247-265).

Głębokie zakorzenienie jedwabnictwa w kulturze chińskiej związane jest z prastarą tradycją wywodzącą się już z neolitu. Najstarsze ślady wykorzystywania jedwabników pochodzą z neolitycznej kultury Yangshao (5000-3000 p.n.e.). Na stanowisku Xiyin w prowincji Shanxi odkryto połowę kokonu jedwabnika. Znalezisko datuje się na 2200-1700 p.n.e. (Peng 2012: 71-72). Początkowo naukowcy nie byli przekonani co do jego prawidłowej identyfikacji. Gdy potwierdziło się, że jest to jednak kokon jedwabnika, powstały kolejne pytania. 
Jeśli kokon ma być dowodem na rozwinięty przemysł włókienniczy, to dlaczego został intencjonalnie przecięty?

Niezbitym dowodem na produkcję tkanin jedwabnych w kulturze Yangshao są tkaniny odkryte na stanowisku Qingtai, Xingyang w prowincji Henan. Są to gazy ${ }^{3}$ typu sha (纱) i luo (罗). Greża ma cechy surowca pochodzącego od udomowionego jedwabnika. Przypuszcza się, że po utkaniu materiały zabarwiono przy użyciu ochry. Tkaniny wydatowano na 3500 r. p.n.e. (Peng 2012: 71-72). Tym samym są najstarszymi znanymi jedwabnymi materiałami.

Kolejną jedwabną tkaninę odkryto na stanowisku Qianshanyang, Wuxing, w prowincji Zhejiang. Jest wykonana splotem płóciennym z nici składających się z ok. 20 nieskręconych jedwabnych włókien. Znalezisko datuje się za na podstawie badań C14 na 2700-2500 p.n.e. (Peng 2012: 72).

Odkrycia te wskazują na to, że udomowienie jedwabnika i jego regularna hodowla sięgają przynajmniej IV tys. p.n.e. Z tego samego okresu pochodzą najstarsze tkaniny wykonane $\mathrm{z}$ włókna opornika łatkowatego (Pueraria thunbergiana) (Kuhn 1988: 39). Nieco młodsze są najstarsze przykłady materiałów utkanych $\mathrm{z}$ ramii indyjskiej (Boehmeria nivea) i konopi (Cannabis sativa) (Kuhn 1988: 23-39). W neolicie na pewno wykonywano gazy oraz tkaniny o splocie płóciennym ${ }^{4}$. Prymitywna technologia tkacka nie pozwalała prawdopodobnie na produkcję tkanin polichromicznych bądź wzorzystych. W tym okresie wykorzystywano proste krosna jarzmowe, czyli poziome warsztaty tkackie przywiązywane do pasa tkacza. Najstarsze odkryto na stanowisku Hemudu. Pochodzi ono z V tys. p.n.e. (Zhao 2015: 420).

Hodowla jedwabnika rozpowszechniła się w epoce brązu. Z czasów panowania dynastii Shang (1600-1046 p.n.e.) pochodzą najstarsze wzmianki o morwie, jedwabnikach oraz jedwabnych tkaninach umieszczone na kościach wróżebnych. Ponadto na epokę brązu datowane są nefrytowe figurki gąsienic (składano je wraz z darami grobowymi w pochówkach z okresu dynastii Shang i Zachodniej Zhou) oraz naczynia i inne precjoza $z$ wyobrażeniem gąsienic. Na wielu brązowych naczyniach odkryto ślady tkanin, natomiast w Anyangu natrafiono na nefrytowy topór owinięty jedwabnym materiałem. Jego ostrze było zdobione scenami tkania jedwabiu (Uhlig 2007: 17).

\footnotetext{
${ }^{3}$ Gaza to luźno tkana, półprzezroczysta, ażurowa tkanina. W gazie właściwej przerwy pomiędzy kolejnymi nićmi wątki i osnowy uzyskuje się przeważnie poprzez przeplatanie dodatkowych nici osnowy na osnowie podstawowej.

${ }^{4} \mathrm{~W}$ splocie płóciennym nieparzyste nici osnowy pokrywają nieparzyste nici wątku, tworząc szachownicę.
} 
Wszystko wskazuje na to, że za czasów panowania dynastii Shang serikultura była bardzo rozwinięta. Za czasów kolejnej dynastii - Zachodniej dynastii Zhou (1046-770 p.n.e.) nastąpił dalszy rozkwit technik tkackich. Z tego okresu pochodzą dowody nie tylko na wykonywanie materiałów płóciennych (juan 绢) i gaz (sha i luo), ale także na powstawanie materiałów o płóciennym wiązaniu i skośnym wzorze (qi 绮) oraz tkanin wzorzystych osnowowych o wiązaniu płóciennym (jin 锦) ${ }^{5}$.

Specjalizacja rzemieślnicza prawdopodobnie nastąpiła w początkach epoki żelaza. Teksty historyczne wymieniają szewców - „tych, co tkają buty" i gaozhe - „tych, co tkają jedwabne materiały” (Peng 2012: 82-83). W tradycyjnej kulturze chińskiej przędzalnictwem i tkactwem zajmowały się kobiety, podczas gdy ogół mężczyzn trudnił się pracami na polu (Rothschild 2014). Domowa produkcja tekstylna funkcjonowała także w kolejnych epokach, ale zapotrzebowanie na luksusowe, wyrafinowane tkaniny, które tkano na skomplikowanych warsztatach tkackich, spowodowało powstanie wyspecjalizowanych ośrodków produkcji. Szerokości i długości tkanin były ustandaryzowane, o czym świadczą zarówno znaleziska tekstylne, jak i teksty historyczne. Z okresu Wschodniej Dynastii Zhou (770-256 p.n.e.) pochodzą pieczęcie z konkretnych warsztatów oraz odciski podobnych stempli na odkrytych tkaninach (Peng 2012: 83).

W okresie Wschodniej Dynastii Zhou tkacze używali przede wszystkim zwykłych krosien jarzmowych, ale pojawiły się już pierwsze krosna pedałowe. W Księdze Mistrza Lie (Liezi) można wyczytać wzmianki o krośnie pedałowym z kilkoma nicielnicami ${ }^{6}$ (Peng 2012: 83).

W okresie Wiosen i Jesieni (770-476 p.n.e.) oraz w epoce Walczących Królestw (476-221 p.n.e.) tkano zarówno proste tkaniny płócienne $\mathrm{z}$ jedną nicią wątku i jedną nicią osnowy (juan) oraz z podwojoną bądź potrojoną nicią osnowy jian (缣, jak i grube i szorstkie tkaniny ti (绨). Popularne były również, znane już w epoce brązu, tkaniny płócienne ze wzorem skośnym (qi). Ponadto produkowano co najmniej trzy rodzaje gazy ( $h h a$, luo i $h u$ 縠). Rozwój krosien pozwolił na tkanie materiałów wzorzystych osnowowych o wiązaniu płócien-

\footnotetext{
${ }^{5}$ Są to tkaniny $\mathrm{z}$ jednym systemem wątku i dwoma systemami osnowy. Osnowa podstawowa razem $\mathrm{z}$ wątkiem wiąże tkaninę $\mathrm{w}$ splocie płóciennym, natomiast różnokolorowa osnowa figurowa tworzy wzór na całej powierzchni materiału.

${ }^{6}$ Nicielnica to pozioma belka w krośnie tkackim, służąca do mechanicznego rozdzielania poszczególnych nici osnowy (np. na parzyste i nieparzyste) w celu utworzenia przesmyku, w który wprowadza się nici wątku.
} 
nym (jin) (Peng 2012: 86-87). W okresie Walczących Królestw pojawiły się także pierwsze dzianiny (Peng 2012: 97-99).

Dekoracje na tkaninach qi z okresu Wschodniej Dynastii Zhou to przede wszystkim kolorowe (ciemnoczerwono-czarno-żółte) paski. Z kolei tkaniny wzorzyste osnowowe o wiązaniu płóciennym (jin) oprócz pionowych pasów dekorowały motywy geometryczne (np. romby), a także motywy feniksów i dzikich kaczek. Z okresu Walczących Królestw pochodzi także sporo jedwabnych tkanin haftowanych. Zdobią je motywy feniksów, smoków, ptaków, a także elementy roślinne i geometryczne. Kompozycja wzoru ujęta jest w sposób subtelny. Najczęściej jest to haft łańcuszkowy, ale zdarza się także atłasek i kładziony. Jedwabne tkaniny docierały na Zachód przede wszystkim za pośrednictwem koczowników. W kurhanie 6 w Pazyryku odkryto przepiękną tkaninę $\mathrm{z}$ wyhaftowanym drzewem, na którego gałęziach spoczywały ptaki (Rudenko 1970: 174). W tym okresie wyroby chińskie sporadycznie opuszczały tereny leżące w orbicie chińskich wpływów. Kolejna epoka przyniosła radykalne zmiany.

Momentem przełomowym w historii Chin było dojście do władzy w 221 r. p.n.e. dynastii Qin. Na czele stanął Qin Shi Huang. Władca słynął z okrucieństwa, mimo to nie można zaprzeczyć, że to za jego rządów zunifikowano chińską kulturę: ujednolicono system monetarny, miary i wagi, rozstaw kół, pismo itd. Rządy dynastii Qin (władcy Qin Shi Huang i jego syna) były krótkie. Już w 206 r. p.n.e. władzę objęła dynasta Han, wprowadzając Chiny w złoty wiek. Podczas czterech wieków jej panowania dokonano niezwykłego postępu w nauce, rozwinięto technologię i wzbogacono kulturę materialną, jak i duchową. Był to także czas, kiedy Państwo Środka otworzyło się na świat. Chińscy emisariusze docierali do ościennych imperiów, a karawany kupieckie przemierzały Azję, co sprawiło, że chińskie tkaniny stały się dobrem luksusowym w Imperium Rzymskim i w Persji.

Początki kontaktów dyplomatycznych i handlowych z Zachodem wiążą się z ekspedycją wysłaną przez cesarza Wudi w celu odnalezienia ludu Yuezhi, który wcześniej był wyparty znad granic cesarstwa przez wojowniczych Xiongnu. Delegacja chińska miała na celu sprzymierzenie się z Yuezhi przeciwko Xiongnu, którzy zagrażali potędze Chin. Cel nie został osiągnięty, ale następstwem wyprawy było wysłanie pierwszych chińskich emisariuszy na dwór partyjskiej Persji (Tucker 2003: 82). Wśród darów znalazł się oczywiście jedwab. Wkrótce surowiec ten stał się głównym towarem importowanym z Chin.

W okresie panowania dynastii Han unowocześniono technologię tkacką. Ikonografia z epoki pozwala na odtworzenie wyglądu podstawowych krosien (Becker 1987: 22-23). Były to proste krosna dwu- 
pedałowe, które wykształciły się prawdopodobnie z krosien jednopedałowych używanych jeszcze do niedawna w Japonii (Broudy 1993: 113-114). Nie wiadomo, czy w okresie tym znane były krosna z podciąganymi licami ${ }^{7}$. Można przypuszczać, że wynaleziono je pod koniec panowania Zachodniej Dynastii Han. Z tego okresu pochodzą najstarsze materiały jin cztero- i pięciokolorowe. Kolejna poszlaka wskazująca na wykorzystywanie tych rozbudowanych warsztatów tkackich pochodzi z Fu o tkaczce (Jifu fu), który powstał w I lub II w. n.e. Znajduje się w nim opis krosna, które bywa interpretowane jako krosno z podciąganymi licami (Kuhn 2012: 57).

Wyrafinowane tkaniny wzorzyste powstawały w oficjalnych warsztatach tkackich. W okresie panowania dynastii Han centra produkcji jedwabniczej znajdowały się w stolicy Chang'an (dzisiejszy Xi'an), w prowincji Shandong oraz w Syczuanie (Zhao 2004: 115). Są to przede wszystkim tkaniny wzorzyste osnowowe o wiązaniu płóciennym. Kolorowe nici wątku figurowego tworzą wzory. Najczęściej osnowy figurowe są w kolorze czerwonym, niebieskim, żółtym, czarnym i białym. Zhao Feng (2010) uważa, że ta kolorystyka jest powiązana $\mathrm{z}$ symbolicznym znaczeniem tych pięciu barw. Mają one odzwierciedlać pięć pozycji: północ, południe, wschód, zachód i środek; pięć planet: Wenus, Jowisza, Merkurego, Marsa i Saturna lub pięć materiałów: metal, drewno, wodę, ogień i ziemię. Wzory to najczęściej motywy chmur (dwa typy) oraz mityczne zwierzęta (smoki, feniksy). Zastanawiające są przedstawienia interpretowane jako wizerunki lwów (Zhang 2013: 100-112), które miałyby pochodzić ze sztuki perskiej, a do Chin dotarłyby za pośrednictwem nomadów. Zwierzęta przedstawione są w sposób schematyczny, dlatego trudno stwierdzić, czy rzeczywiście są to lwy, a nie na przykład powszechne w sztuce Chin tygrysy. Niektóre tkaniny jin zdobią także krótkie napisy.

W okresie panowania dynastii Han pojawiły się tkaniny wzorzyste wątkowe z wysnuwaną osnową (rongquan jin 线圈锦). Technika ta nazywana była tkaniem haftów. Z dokumentu z 54 r. n.e. wynika, że była rzadko stosowana ze względu na jej skomplikowany charakter. W tym samym okresie zaprzestano produkcji tego typu tkanin (Peng 2012: 126).

\footnotetext{
${ }^{7}$ Składało się ono z kilku nicielnic (od dwóch do ośmiu), przez które przewleczona była osnowa podstawowa (tworząca tło), oraz kilkunastu do kilku tysięcy lic (sznurki z oczkiem i pętelkami przedłużone sznurami podciągowymi) z przeciągniętymi nićmi osnowy figurowej. Dzięki takiemu mechanizmowi możliwe było wyciąganie pojedynczych nici osnowy, co pozwalało na tworzenie pełnofigurowych wzorów. W procesie tkania potrzebne były dwie osoby - tkacz i jego pomocnik podciągający sznury podciągowe.
} 
Dużym uznaniem cieszyły się tzw. adamaszki. Już w czasach panowania dynastii Zhou znane były adamaszki qi oraz han qi (汉绮), jednak dopiero w czasach dynastii Han technika ta przeżywała prawdziwy rozkwit. Tkaniny qi składają się z dwóch systemów osnowy i jednego systemu lub dwóch systemów wątku. Rdzeń (tło) materiału tkano splotem płóciennym, natomiast wzór tworzono, przeplatając nici dodatkowej osnowy w sposób skośny $1 / 3$. Tkaniny han qi powstawały w bardzo podobny sposób, ale osnowa dodatkowa nie pojawiała się na całej przestrzeni wzoru. W rzeczywistości te dwa typy tkanin są protolampasami, a nie adamaszkami. Według Penga Hao (2012: 128) z czasów panowania dynastii Han pochodzą najstarsze adamaszki ling (绫), czyli tkaniny o splocie skośnym zarówno tła, jak i wzoru, jednak prawdopodobnie termin ling początkowo odnosił się jedynie do bardzo delikatnych tkanin produkowanych w Shandongu, natomiast adamaszki ling zaczęto tkać znacznie później, przypuszczalnie w III-V w. n.e. (Żuchowska 2016: 222). Tkaniny ling były niezwykle cenione. W okresie panowania dynastii Jin wraz z tkaninami jin zakazano ich domowej produkcji, do której potrzebny był zresztą bardzo rozbudowany warsztat tkacki. Źródła historyczne mówią, że krosno do produkcji tkanin ling miało od 50 do 60 nicielnic i od 50 do 60 pedałów (Peng 2012: 130).

Z okresu panowania dynastii Han pochodzi także bogaty zbiór gaz. Są to głównie typy znane ze wcześniejszych epok (sha, luo, hu). Gazy sha są to zwykłe tkaniny płócienne tkane bardzo luźno w celu uzyskania delikatnego, przezroczystego materiału. W przypadku tych tkanin nie stosuje się splotów gazejskich. Sploty te są charakterystyczne dla gładkich gaz suluo (素罗) i gaz wzorzystych wenluo (纹 罗). Gazy hu występowały najrzadziej.

Najwięcej tkanin z czasów panowania dynastii Han pochodzi z Kotliny Tarymskiej i Kotliny Turfańskiej, które były wówczas pod silnymi wpływami Chin. Tkaniny zachowały się na wielu stanowiskach (Loulan, Niya, Yingpan itp.) dzięki skrajnie suchemu klimatowi występującemu na pustyni Takla Makan. Pokaźny zbiór tkanin pochodzi również z Mawangdui w prowincji Hunan. Tekstylia zostały odkryte głównie w grobie nr I. Znajdował się w nim pochówek kobiecy z 168 r. p.n.e. W grobowcu tym oprócz gaz, adamaszków i tkanin haftowanych (najczęściej przedstawiano opływowe motywy roślinne i geometryczne) odkryto najstarsze znane tkaniny farbowane przez matrycę i stemplowane (Peng 2012: 132-133). Kolejną techniką zdobniczą było malowanie. Z grobowców w Mawangdui pochodzą przepiękne przykłady malowanych chorągwi. 
Wraz z upadkiem dynastii Han rozbite Chiny pogrążyły się w konfliktach pomiędzy rywalizującymi państwami. Po okresie Trzech Królestw (ok. 220-280 n.e.) do władzy doszła dynastia Jin (265-420 n.e.). $\mathrm{Na}$ początku $\mathrm{V}$ w. n.e. imperium znów pogrążyło się w chaosie (Okres Dynastii Północnych i Południowych 420-581 n.e.). Ponowne zjednoczenie nastało dopiero dzięki dynastii Sui (581-618 n.e.). W 618 r. n.e. władzę przejęła dynastia Tang, która odbudowała potęgę Chin.

Niewiele wiadomo na temat tkactwa w okresie rozbicia chińskiego imperium. Najwięcej tkanin z tej epoki pochodzi z Chińskiego Turkiestanu Wschodniego. Ostatnio odkryto także pokaźny zbiór chińskich tekstyliów w Dulan (region należał do Imperium Tybetańskiego) (Zhao 2002: 72-109).

Na przełomie V/VI w. n.e. Chiny utraciły monopol na jedwab. Według legendy przekazanej przez Xuanzanga, buddyjskiego mnicha podróżującego przez Azję, nasiona morwy i jajeczka jedwabnika zostały przemycone do oazy Chotan (Kotlina Tarymska) przez chińską księżniczkę wydaną za lokalnego księcia (Xuanzang 1884: 318-319). Nie wiadomo, ile jest prawdy, a ile mitu w historii o przemycie jedwabiu, pewne jest jednak, że około $\mathrm{V}$ w. n.e. jedwab zaczął być produkowany także w Azji Środkowej, a niedługo później w Persji. Pilnie strzeżona tajemnica jedwabnictwa, za której ujawnienie groziła kara śmierci, przedostała się z Chin na Zachód. Ponadto w okresie tym w tkactwie chińskim pojawiły się wpływy irańskie (Kossowska 2015: 35-49). Na cmentarzysku w Astanie (Kotlina Turfańska) oprócz tradycyjnych tkanin chińskich odkryto materiały z chińską ikonografią wykonane splotem wzorzystym wątkowym o wiązaniu płóciennym (IV w. n.e.). W VI i VII w. n.e. powstawały tkaniny jin z motywami perskimi. Co ciekawe, te same wzory znajdują się na tkaninach wzorzystych osnowowych o wiązaniu skośnym. Tkaniny te były pierwowzorem chińskich samitów ${ }^{8} \mathrm{z}$ motywami perskimi, które zaczęły powstawać w ośrodkach chińskich (np. w Syczuanie) na przełomie VII i VIII w. n.e. (Yokohari 2006: 155-174).

W okresie panowania dynastii Tang doszło do zmiany zarówno $\mathrm{w}$ technice, jak i zdobnictwie. O ile w poprzednich epokach nie ma dowodu na używanie krosien z podciąganymi licami, o tyle w okresie panowania dynastii Tang z pewnością były już one znane. Tkaniny jin zaczęły być wypierane przez samity. Przeważnie zdobiły je syme-

\footnotetext{
${ }^{8}$ Tkaniny wzorzyste wątkowe o wiązaniu skośnym. Początkowo tkaniny te były charakterystyczne dla warsztatów bliskowschodnich i środkowoazjatyckich. Dopiero od końca VII w. n.e. zaczęły być wytwarzane przez tkaczy chińskich.
} 
tryczne motywy roślinne ujęte $\mathrm{w}$ formie rozety bądź medalionu. Ponadto adamaszki qi i han qi zastąpiły adamaszki ling - tkaniny o skośnym splocie wzoru i tła. Rozwój nastąpił także na poziomie technik dekoracyjnych. Wciąż popularne były hafty, które w okresie dynastii Tang osiągnęły apogeum kunsztu. Niektóre tkaniny w całości były pokryte haftem, inne były zdobione przez złote bądź srebrne plakietki. W epoce tej popularność zdobyły techniki zdobienia przez rezerwowanie wybarwien. Tkaniny obwiązywano i moczono w barwniku lub nanoszono $\mathrm{w}$ miejsce wzoru ciepły wosk, po czym moczono tkaninę w barwniku (batikowanie). Aby uzyskać powtarzający się wzór, tkaninę zaciskano $\mathrm{w}$ bloku drewna $\mathrm{z}$ wyrzeźbionym motywem. W otwory tworzące motyw wlewano / nanoszono substancję odporną na barwnik - wosk, popiół itp. (Watt 2004: 342).

W kolejnych epokach tkaniny chińskie nie traciły na popularności, zresztą do dzisiaj jedwab jest jednym $\mathrm{z}$ najszlachetniejszych surowców włókienniczych. Niniejsze opracowanie jest tylko zarysem historii tkactwa chińskiego od neolitu do panowania dynastii Tang. Sztuka jedwabnicza była tak rozwinięta, że nie sposób omówić wszystkich jej aspektów.

\section{Bibliografia}

Becker, John. 1987. Pattern and Loom. Copenhagen: RHODOS.

Boulnois, Luce. 1968. Szlakiem Jedwabiu. Tłum. Tadeusz Zabłudowski. Warszawa: PWN.

Broudy, Eric. 1993. The book of looms. A history of handloom from ancient times to the present. Hanover - London: Brown University Press.

Good, Irene. 1995. On the question of silk in pre-Han Eurasia, Antiquity 69, 266 (1995), 959-968.

Good, Irene, Jonathan Mark Kenoyer, Richard Meadow. 2009. New Evidence for Early Silk in the Indus Civilization, Archaeometry 51, 3, 457-466.

Kajdańska, Aleksandra, Edward Kajdański. 2007. Jedwab. Szlakami dżonek i karawan. Warszawa: Książka i Wiedza.

Kossowska, Dominika. 2015. Analiza powstawania synkretycznych stylów zdobniczych w Azji Środkowej w VI-VIII w. n.e. na podstawie tkanin z Kotliny Turfańskiej, Studia Azjatystyczne 1, 35-49.

Kuhn, Dieter. 1988. Textile Technology: Spinning and Reeling, Joseph Needham (red.) Science and Civilization in China vol. 5 Chemistry 
and Chemical Technology, part IX. Cambridge - New York - New Rochelle - Melbourne - Sydney: Cambridge University Press.

Kuhn, Dieter, Zhao Feng. 2012. Chinese Silks. New Haven - London Beijing: Yale University Press, Foreign Language Press.

Kuhn, Dieter. 2012. Reading the Magnificence of Ancient and Medieval Chinese Silks: Dieter Kuhn, Zhao Feng (red.). Chinese Silks. New Haven - London - Beijing: Yale University Press, Foreign Language Press, 1-64.

Michałowska, Marta. 2006. Leksykon włókiennictwa. Warszawa: Krajowy Ośrodek Badań i Dokumentacji Zabytków w Warszawie.

Nahlik, Adam. 1971. Zarys historii jedwabnej tkaniny dekoracyjnej do końca XVIII w. Toruń: Uniwersytet Mikołaja Kopernika.

Peng Hao. 2012. Sericulture and Silk Weaving from Antiquity to the Zhou Dynasty: Dieter Kuhn, Zhao Feng (red.). Chinese Silks. New Haven - London - Beijing: Yale University Press, Foreign Language Press, 65-114.

Rothschild, Norman Harry. 2014. Rhetoric of the Loom: Discursive Weaving Women in Chinese and Greek Traditions, seria Sino-Platonic Papers.

Rudenko, Sergei, Ivanovich. 1970. Frozen tombs of Siberia: The Pazyryk Burials Of Iron Age Horsemen. London: Dent.

Uhlig, Helmut. 2007. Jedwabny Szlak. Kultury Antyku Między Chinami A Rzymem. Tłum. Janusz Danecki. Katowice: Książnica.

Ulanowska, Agata. 2013. Egejskie techniki tkackie $w$ epoce brazu. Zastosowanie archeologii eksperymentalnej $w$ badaniach nad włókiennictwem egejskim. Nieopublikowana praca doktorska obroniona na Wydziale Historycznym Uniwersytetu Warszawskiego.

Tucker, Jonathan. 2003. Silk Road: art and history. London: Philip Wilson Publishers.

Wang, Helen. 2013. Textiles as Money on the Silk Road?, Journal of the Royal Asiatic Society, 23, 2 (2013), 165-174.

Xuanzang. 1884. Si-Yu-Ki: Buddhist Record of the Western World, vol. II. Tłum. Samuel Beal. London: Trübner \& Co., Ludgate Hill.

Yokohari, Kazuko. 2006. The Hōryū-ji Lion-hunting Silk and Related Silks: Regula Schorta (red.). Central Asian Textiles and their Contexts in the Early Middle Ages. Riggisberg: Abegg-Stiftung, 155-173.

Zhang Wen, Xu Chunzhong, Wu Zhuo, Qiu Yiping. 2013. A Study on the Auspicious Animal Motifs on Han Textiles in Ancient China, The Silk Road 11 (2013), 100-112.

Zhao Feng. 2002. Recent excavations of textiles in China. Hong Kong: ISAT / Costume Squad Ltd. 
Zhao Feng. 2004. The evolution of textiles along the Silk Road: James C. Y. Watt (red.). China: Dawn of the Golden Age 200-750 A.D. New York: The Metropolitan Museum of Art, New Haven London: Yale University Press, 67-78.

Zhao Feng. 2010. Woven Color in China: The Five Colors in Chinese Culture and Polychrome Woven Textiles, Textile Society of America Symposium Proceedings. Paper 63, http://digitalcommons.unl.edu/tsaconf/63, dostęp: 1.08.2016.

Zhao Feng. 2015. Weaving Technology.: Yongxiang Lu (red.). A history of Chinese Science and Technology, Tom 2. Verlag - Berlin - Heidelberg: Springer, 379-493.

Żarnowiecki, Longin. 1915. Historya tkanin jedwabnych. Kijów: Drukarnia Polska w Kijowie.

Żuchowska, Marta. 2016. "Roman Textiles" in the Hou Han Shu. A 5th Century Chinese Vision versus Roman Reality, ANABASIS Studia Classica et Orientalia 6 (2015), 216-244.

\begin{abstract}
:
When the empress was drinking tea... - A history of Chinese silk from Neolithic to the Tang dynasty

Chinese silk has a long history. The sericulture began in Neolithic times. Before the Western Zhou period (1600-1046 BC) the most popular textiles were plain weaved (juan) and gauzes (sha and luo). During the kingship of the Zhou dynasty (Western and Eastern) new types of textiles began to be woven, for example: pseudo-damasks ( $q i$ and han qi) and warp faced compound tabby (jin). The most beautiful four-color, and five-color jin fabrics were woven in Han dynasty (206 BC-220 AD). In this period China came in contact with the Western world. It was the beginning of the so-called Silk Road. Weaving technique still flourished during the next periods. The first samit textiles (often decorated with Persian motives) were weaved during the Tang dynasty. The sericulture was a ritual practiced in the common households and royal courts. The silkworm had its own temples and goddess.
\end{abstract}

Keywords: silk, textiles, Silk Road, China 